\title{
PENGARUH MIKORIZA TERHADAP PENYAKIT LAYU FUSARIUM (Fusarium oxysporum) PADA TEMBAKAU (Nicotiana tabacum L.) DALAM MEDIA PASIR KUARSA MENGANDUNG KOMPOS AMB-P0K
}

\section{Effect of Mycorrhiza on Fusarium Wilt Disease (Fusarium oxysporum) Tobacco (Nicotiana tabacum L.) in Quartz Sand Media Containing Compost AMB-P0K}

\author{
Dony Firman Fajariza*, Anton Muhibuddin, Antok Wahyu Sektiono \\ Jurusan Hama dan Penyakit Tumbuhan, Fakultas Pertanian Universitas Brawijaya. Jl. Veteran, Malang 65145, \\ Jawa Timur, Indonesia. Tel.: +62-341-551665, 565845. Fax.: +62-341-560011 \\ *Penulis korespondensi: donyfirmanf@gmail.com
}

\begin{abstract}
Sand is one of the planting media, but the use of sand as a planting medium is still rare due to the low nutrient content. Quartz sand needs the addition of compost to support plant growth. Mycorrhiza can also be added to the growing media. Mycorrhiza is a soil fungus that can symbiosis with the host plant's roots and has a broad influence on pathogenic microorganisms. Mycorrhiza can also increase secondary metabolites in plants. The compound which is the initial signal for plants to form secondary metabolites is salicylic acid. This research aimed to investigate effect mycorrhiza increase plant growth, the content of salicylic acid and reduce the attack of F. oxysporum fungi that cause Fusarium wilt in tobacco plants. This experiment used a completely randomized design with mycorrhiza dose treatment consisting of 6 treatments that are Control (Soil), M0 (AMB-P0K $+0 \mathrm{~g}$ polybag-1 $^{-1}$ M1 (AMB-P0K $+10 \mathrm{~g} \mathrm{polybag}^{-1}$ ), M2 (AMB-P0K $+20 \mathrm{~g}^{\text {polybag- }}{ }^{-1}$ ), M3 (AMB-P0K +30 g polybag- ${ }^{-1}$ ), M4 (AMB-P0K +40 g polybag $^{-1}$ ) with each treatment consisting of 5 replications. The results showed that AMB-POK + mycorrhiza was significant at plant height, number of leaves, leaf area, disease index, pathogen incubation and SA contain.
\end{abstract}

Keywords: AMB-POK, Fusarium wilt, mycorrbiza, quartz sand

\section{Pendahuluan}

Pasir merupakan salah satu media tanam, namun penggunaan pasir sebagai media tanam masih jarang dikarenakan kandungan unsur hara yang rendah. Salah satu jenis pasir yang dapat digunakan adalah pasir kuarsa. Pasir kuarsa adalah pasir yang diperoleh dari tailing atau ampas bekas tambang kaolin, emas, timah putih dan bauksit (Suprapto, 2007). Menurut Pratiwi et al. (2012) pasir kuarsa perlu penambahan kompos agar mendukung untuk pertumbuhan tanaman. Selain penambahan kompos, mikoriza juga dapat ditambahkan ke dalam media tanam. Mikoriza adalah cendawan tanah yang dapat bersimbiose dengan akar tanaman inang, dan mempunyi pengaruh yang luas terhadap mikroorganisme yang bersifat patogen. Media tanam pasir merupakan media tanam yang sesuai untuk pertumbuhan mikoriza. Pasir mempunyai aerasi yang baik sehingga jamur mikoriza dapat berkembang dengan baik. Febriani et al.. (2017) menyatakan bahwa media tanam pasir baik untuk kolonisasi mikoriza dan dapat meningkatkan persentase kolonisasi mikoriza dengan tanaman sebanyak 85,29 \% sedangkan pada media tanam tanah hanya $53,79 \%$, sekam $19,32 \%$ dan cocopeat $16,39 \%$. Mikoriza juga dapat meningkatkan senyawa metabolit sekunder pada tanaman. Menurut penelitian Guo et al. (2010) mikoriza meningkatkan 
alkaloid pada tanaman medis, senyawa alkaloid yang meningkat adalah ephedrine, camptothecin, and alliin. Tidak hanya meningkatkan alkaloid dan terpenoid namun mikoriza juga dapat meningkatkan senyawa fenolik pada tanaman. Zubek et al. (2015) melaporkan bahwa mikoriza meningkatkan senyawa fenolik pada tanaman Viola tricolor, Yang et al. (2017) juga menyatakan mikoriza dapat meningkatkan senyawa fenolik pada tanaman Salvia sp. Senyawa yang merupakan sinyal awal untuk tanaman membentuk metabolit sekunder adalah asam salisilat. Asam salisilat memberi sinyal kepada enzim phenylalanine ammonia-lyase (PAL) yang kemudian PAL bernsitesis dengan enzim lainnya untuk menghasil metabolit sekunder pada tanaman. Tujuan penelitian ini adalah untuk mempelajari apakah pengaplikasian mikoriza pada media pasir kuarsa yang mengandung kompos AMB-P0K dapat meningkatkan pertumbuhan tanaman, mengurangi serangan jamur F. oxysporum penyebab layu Fusarium dan pengaruhnya terhadap kandungan asam salisilat tanaman tembakau.

\section{Bahan dan Metode}

Penelitian dilaksanakan di Laboratorium Penyakit Tumbuhan, Fakultas Pertanian, Universitas Brawijaya Malang, Rumah Kaca UIN Maulana Malik Ibrahim dan Laboratorium Universitas Machung. Penelitian ini menggunakan rancangan acak lengkap dengan perlakuan 6 dosis mikoriza yaitu $\mathrm{K}$ (tanah konvensional), M0 (AMB-P0K $+0 \mathrm{~g}_{\text {polybag- }}{ }^{-1}$ ) M1 (AMB-P0K $+10 \mathrm{~g}^{\text {polybag-1 }}{ }^{-1}$ ), M2 (AMB$\mathrm{P} 0 \mathrm{~K}+20 \mathrm{~g} /$ polybag), M3 (AMB-P0K $+30 \mathrm{~g}$ polybag-1), M4 (AMB-P0K +40 g polybag $^{-1}$ ). Polybag yang digunakan ukuran $5 \mathrm{~kg}$. Setiap perlakuan terdapat 5 ulangan. Data yang diperoleh pada pengamatan tinggi, jumlah daun, indeks penyakit dan luas daun diolah dengan ANOVA yang dilanjutkan dengan uji Duncan Multiple Range Test (DMRT) pada taraf 5\%. Data yang diperoleh pada pengamatan kandungan asam salisilat diuji dengan uji $\mathrm{T}$ satu sampel pada taraf 5\%.

\section{Pembuatan media tanam AMB-POK}

Media tanam AMB - POK dibuat dengan mencampurkan Kompos AMB - POK dengan pasir kuarsa dan kompos daun dengan perbandingan 6:3:1. Kompos AMB - POK membutuhkan bahan utama berupa limbah tomat, rimpang kunyit, dan daun rumput gajah dengan perbandingan 2: 1: 1. Bahan tersebut dihancurkan dengan mesin penghancur yang terdapat di UPT Kompos Universitas Brawijaya. Bahan yang telah dihancurkan kemudian ditambahkan EM4 dan molase. Kemudian tutup bahan dan biarkan selama 14 hari. Kelembaban, suhu, dan sirkulasi udara dalam proses pengomposan harus dijaga dengan menyemprotkan sedikit air seminggu sekali dan mengaduk kompos (Muhibuddin, 2018).

\section{Penyemaian tanaman tembakau}

Persamain tanaman tembakau dilakukan di nampan yang telah diisi oleh tanah dan pupuk kandang dengan perbandingan 1:1. Benih tembakau ditaburkan diatas nampan dan disiram setiap hari. Setelah 35 hari bibit dipindahkan ke media tanam AMB - P0K.

\section{Pemberian dosis mikoriza}

Pemberian mikoriza dilakukan 1 minggu sebelum tanaman tembakau pindah tanam. Mikoriza diberikan tepat ditengah media tanam AMB-P0K dengan dosis sesuai perlakuan.

\section{Pembuatan media PDA dan identifikasi Fusarium oxysporum}

Pembuatan media Potato Dextrose Agar (PDA) dilakukan dengan cara menyiapkan kentang 250 $\mathrm{g}, 20 \mathrm{~g}$ dextrose, $20 \mathrm{~g}$ agar dan 1 liter aquades. Umbi kentang dicuci dengan air bersih, dikuliti dan dipotong kecil dadu. Potongan kentang dimasukkan ke dalam panci yang telah berisi $1000 \mathrm{ml}$ air kemudian direbus selama 30 menit hingga mendidih dan kentang sedikit lunak. Setelah itu ditiriskan dan didinginkan selama 3 menit. Air rebusan tersebut disaring dan ditambahkan dextrose sebanyak $20 \mathrm{~g}$ dan agar $20 \mathrm{~g}$, kemudian ditambahkan chloramphenicol agar tidak terkomtaminasi bakteri kemudian dituangkan ke dalam botol scot. Platting media dilakukan di tempat steril yaitu LAFC. Pertama sebelum melakukan platting adalah melakukan penyemprotan alkohol dalam LAFC kemudian LAFC ditutup dan Lampu UV dinyalakan selama 30 menit kemudian blower dinyalakan agar udara dari luar tidak masuk ke dalam LAFC. Alat dan bahan dimasukkan ke dalam LAFC. 
Tangan disterilkan dengan alkohol sebelum platting media. Bunsen dinyalakan lalu cawan petri yang telah disterilkan didekatkan pada Bunsen, lalu media PDA pada botol kaca dimasukkan ke cawan petri sedikit demi sedikit. Cawan petri yang telah diberi media di wrapping agar tidak terkontaminasi. Jamur F. oxysporum yang digunakan dalam penelitian ini didapatkan dari Balai Penelitian Tanaman Pemanis dan Serat (Balittas). Isolat diidentifikasi secara makroskopis dan mikroskopis. Identifikasi dilakukan dengan cara koloni jamur F. oxysporum sebagian diambil dan diletakkan diatas gelas objek steril, ditetesi aquades steril lalu ditutup dengan cover glass dan diinkubasi selama 4 hari. Setelah 4 hari diamati di bawah mikroskop dengan perbesaran 400x. Hasil pengamatan diidentifikasi menggunakan buku Pictorial Altas of Soil and Seed Fungi.

\section{Inokulasi patogen}

Inokulasi spora $\mathrm{F}$. oxysporum dilakukan pada saat tanaman tembakau 30 hari setelah pindah tanam ke dalam media AMB - P0K. Media tanam digali sebagian hingga terlihat akar tanaman, kemudian akar tanaman tembakau dipotong dengan cara mengguting dengan ukuran $1 \mathrm{~cm}$ dan suspensi spora $F$. oxysporum sebanyak $10 \mathrm{ml}$ disiram ke akar yang telah dipotong.

\section{Pengamatan dan pengumpulan data}

Pengamatan pada tanaman percobaan meliputi tinggi tanaman, jumlah daun, luas daun, inkubasi patogen, intensitas penyakit dan kandungan asam salisilat. Pengamatan tinggi tanaman, jumlah daun dilakukan setiap 1 minggu sekali dimulai dari 1 MST. Tinggi tanaman diukur mulai dari permukaan tanah sampai pucuk tanaman tertinggi. Penghitungan jumlah daun dilakukan dengan cara menghitung jumlah daun pada setiap tanaman, daun yang dihitung meliputi daun yang sudah terbuka secara sempurna (tidak termasuk kuncup daun). Tinggi dan jumlah daun kemudian dihitung laju pertumbuhannya. Pengamatan luas daun dilakukan pada $8 \mathrm{mst}$, luas daun dihituung menggunakan aplikasi Easy Leaf Area. Masa inkubasi diamati setiap hari sejak hari pertama setelah inokulasi sampai timbulnya gejala. Setelah itu dilakukan penghitungan intensitas penyakit dilakukan dengan mencatat jumlah tanaman yang bergejala layu fusarium kemudian dihitung menggunakan metode skoring selama 4 minggu setelah inokulasi (MSI). Skoring penyakit berdasarkan Gao et al. (1994) : $0=$ Tanaman tidak terserang penyakit, $1=1-25 \%$ daun tanaman terserang layu fusarium, $2=26-$ $50 \%$ daun tanaman terserang layu fusarium, 3 $=51-75 \%$ daun tanaman terserang layu fusarium, $4=75 \%-100 \%$ tanaman terserang layu fusarium. Berikut ini adalah rumus intensitas penyakit:

$$
\frac{\sum(n \times v)}{Z \times N} \times 100 \% .
$$

dimana

$$
\begin{aligned}
\mathrm{n} & =\begin{array}{l}
\text { Jumlah tanaman dari setiap } \\
\text { kategori serangan }
\end{array} \\
\mathrm{v} & =\text { Skor serangan layu fusarium } \\
\mathrm{Z} & =\begin{array}{l}
\text { Skor tertinggi serangan layu } \\
\text { fusarium }
\end{array} \\
\mathrm{N} & =\text { Total tanama yang diamati }
\end{aligned}
$$

Pengamatan uji asam salisilat menggunakan sampel akar tanaman tembakau. Pengambilan sampel dilakukan secara komposit yaitu mengumpulkan setiap akar pada setiap perlakuan. Uji asam salisilat dilakukan menggunakan spektrofotometer yang absorbansinya diukur pada panjang gelombang $278 \mathrm{~nm}$. Metode ekstrasi merupakan modifikasi dari metode (Widjayanti, 2007). Larutan induk asam salisilat dibuat dengan konsentrasi 0.1 $\mathrm{mg} / \mathrm{ml}$ dan selanjutnya digunakan untuk membuat larutan standart asam salisilat $0.001 \%$. Akar tanaman ditimbang dan dipanaskan pada oven selama 24 jam dengan suhu $80^{\circ} \mathrm{C}$ kemudian diambil sampel sebanyak $0.5 \mathrm{~g}$. Akar yang sudah kering ditambahkan $25 \mathrm{ml}$ klorofom dan direndam selama 24 jam. $600 \mu$ l ekstrak diencerkan menjadi $3 \mathrm{ml}$ menggunakan klorofom kemudian diukur dengan Spektrofotometer UV-VIS JASCO V-760.

\section{Hasil dan Pembahasan}

\section{Laju pertumbuhan tinggi tanaman}

Hasil analisis ragam menghasilkan perbedaan nyata pada 8 mst (Tabel 1). Perlakuan M1 memiliki laju pertumbuhan terkecil yaitu sebesar 18.4\% dan M2 mempunyai laju pertumbuhan tertinggi sebesar $33.6 \%$, namun M2 tidak berbeda nyata dengan perlakuan kontrol. 
Mikoriza dapat bersimbiosis dengan tanaman sehingga dapat membantu penyerapan unsur hara pada tanaman sehingga tanaman dapat tumbuh lebih baik. Menurut (Abror dan Mauludin, 2015) pemberian mikoriza dapat meningkatkan tinggi tanaman cabai rawit.

Tabel 1. Laju pertumbuhan tinggi tanaman.

\begin{tabular}{cccccccc}
\hline Perlakuan & \multicolumn{7}{c}{ Rata Rata Laju Pertumbuhan Tinggi Tanaman Tembakau (\%) } \\
\cline { 2 - 8 } & 2 MST & 3 MST & 4 MST & 5 MST & 6 MST & 7 MST & 8 MST \\
\hline Kontrol & $43.1 \mathrm{a}$ & $33.9 \mathrm{a}$ & $105.5 \mathrm{a}$ & $33.5 \mathrm{a}$ & $45.1 \mathrm{a}$ & $43.9 \mathrm{a}$ & $32.6 \mathrm{~b}$ \\
M0 & $38.8 \mathrm{a}$ & $37.3 \mathrm{a}$ & $127.9 \mathrm{a}$ & $45.5 \mathrm{a}$ & $48.4 \mathrm{a}$ & $45.4 \mathrm{a}$ & $19.7 \mathrm{ab}$ \\
M1 & $43.1 \mathrm{a}$ & $59.2 \mathrm{a}$ & $142.0 \mathrm{a}$ & $39.0 \mathrm{a}$ & $53.6 \mathrm{a}$ & $33.1 \mathrm{a}$ & $18.4 \mathrm{a}$ \\
M2 & $47.4 \mathrm{a}$ & $55.7 \mathrm{a}$ & $112.4 \mathrm{a}$ & $50.2 \mathrm{a}$ & $46.3 \mathrm{a}$ & $45.7 \mathrm{a}$ & $33.6 \mathrm{~b}$ \\
M3 & $59.3 \mathrm{a}$ & $55.4 \mathrm{a}$ & $109.8 \mathrm{a}$ & $49.3 \mathrm{a}$ & $37.4 \mathrm{a}$ & $39.9 \mathrm{a}$ & $33.5 \mathrm{~b}$ \\
M4 & $58.3 \mathrm{a}$ & $44.3 \mathrm{a}$ & $104.1 \mathrm{a}$ & $50.1 \mathrm{a}$ & $38.9 \mathrm{a}$ & $36.7 \mathrm{a}$ & $27.1 \mathrm{~b}$ \\
\hline
\end{tabular}

Keterangan: Bilangan yang diikuti huruf yang sama pada kolom yang sama menunjukkan tidak nyata pada uji DMRT $5 \%$.

\section{Laju pertumbuhan jumlah daun}

Tanaman tembakau yang diberi perlakuan mikoriza mengalami laju pertumbuhan daun lebih cepat tiap minggunya. Hasil analisis ragam menghasilkan perbedaan nyata pada $8 \mathrm{mst}$ (Tabel 2). Perlakuan kontrol dan M0 berbeda nyata dengan setiap perlakuan. M1 memiliki laju pertumbuhan daun tertinggi yaitu sebesar
11.3\%. Laju pertumbuhan daun pada perlakuan kontrol memiliki hasil terendah yaitu $-1.8 \%$ dikarenakan daun pada perlakuan kontrol terserang oleh penyakit layu fusarium. Hasil yang sama juga didapatkan pada penelitian yang dilakukan Valentine et al. (2017) dimana penggunaan mikoriza menghasilkan perbedaan nyata pada jumlah daun tamanan melon yang tidak menggunakan mikoriza.

Tabel 2. Laju pertumbuhan jumlah daun.

\begin{tabular}{ccrrrrrr}
\hline Perlakuan & \multicolumn{6}{c}{ Rata Rata Laju Pertumbuhan Jumlah Daun Tanaman Tembakau (\%) } \\
\cline { 2 - 8 } & 2 MST & 3 MST & 4 MST & 5 MST & 6 MST & 7 MST & 8 MST \\
\hline Kontrol & $30.0 \mathrm{a}$ & $23.3 \mathrm{a}$ & $26.2 \mathrm{a}$ & $12.2 \mathrm{a}$ & $14.2 \mathrm{a}$ & $10.3 \mathrm{a}$ & $-1.8 \mathrm{a}$ \\
M0 & $30.0 \mathrm{a}$ & $35.0 \mathrm{a}$ & $26.1 \mathrm{a}$ & $18.1 \mathrm{a}$ & $19.6 \mathrm{a}$ & $15.1 \mathrm{a}$ & $-1.2 \mathrm{a}$ \\
M1 & $34.0 \mathrm{a}$ & $36.3 \mathrm{a}$ & $26.7 \mathrm{a}$ & $15.0 \mathrm{a}$ & $21.5 \mathrm{a}$ & $8.8 \mathrm{a}$ & $11.3 \mathrm{~b}$ \\
M2 & $29.0 \mathrm{a}$ & $24.0 \mathrm{a}$ & $21.0 \mathrm{a}$ & $30.4 \mathrm{a}$ & $13.6 \mathrm{a}$ & $12.2 \mathrm{a}$ & $10.8 \mathrm{~b}$ \\
M3 & $32.0 \mathrm{a}$ & $28.9 \mathrm{a}$ & $24.6 \mathrm{a}$ & $19.3 \mathrm{a}$ & $12.7 \mathrm{a}$ & $11.6 \mathrm{a}$ & $7.4 \mathrm{~b}$ \\
M4 & $41.3 \mathrm{a}$ & $35.3 \mathrm{a}$ & $21.5 \mathrm{a}$ & $15.1 \mathrm{a}$ & $20.5 \mathrm{a}$ & $9.4 \mathrm{a}$ & $9.9 \mathrm{~b}$ \\
\hline
\end{tabular}

Keterangan: Bilangan yang diikuti huruf yang sama pada kolom yang sama menunjukkan tidak nyata pada uji DMRT 5\%.

\section{Luas daun}

Luas daun terbesar terdapat pada perlakuan M4 kemudian diikuti dengan perlakuan M1, M3, M0 dan M2 (Tabel 3). Luas daun terkecil terkecil terdapat pada variabel kontrol dengan selisih $242 \mathrm{~cm}^{2}$ dengan perlakuan M4. Pada penelitian Yadav et al. (2017) mikoriza juga dapat meningkatkan luas daun mikropragasi tanaman Spilanthes acmella Murr., meningkatkan luas daun benih tanaman kopi dan meningkatkan luas daun tanaman wijen sebesar 136\% (Boureiman et al., 2007), serta dapat meningkatkan luas daun tanaman Zelkova serrata yang di tanaman dalam lahan salin (Wang et al., (2019). Variabel pengamatan seperti laju pertumbuhan tinggi tanaman dan jumlah daun serta luas daun menunjukan bahwa perlakuan pemberian mikoriza mempunya nilai yang paling tinggi di setiap pengamatan. Mikoriza dapat bersimbiosis dengan akar tanaman dan meningkatkan penyerapan unsur hara pada tanaman. 
Jurnal Tanah dan Sumberdaya Lahan Vol 7 No 1 : 31-38, 2020

e-ISSN:2549-9793, doi: 10.21776/ub.jts1.2020.007.1.5

Tabel 3. Luas daun tanaman tembakau.

\begin{tabular}{ccccccc}
\hline Perlakuan & \multicolumn{5}{c}{ Rata - Rata Luas Daun Tanaman Tembakau 8 mst (cm $\mathbf{c m}^{2}$} \\
\cline { 2 - 7 } & Kontrol & M0 & M1 & M2 & M3 & M4 \\
\hline Luas Daun & $390,1 \mathrm{a}$ & $494,46 \mathrm{~b}$ & $510,89 \mathrm{~b}$ & $469,46 \mathrm{ab}$ & $504,59 \mathrm{~b}$ & $632,4 \mathrm{c}$ \\
\hline
\end{tabular}

Keterangan: Bilangan yang diikuti huruf yang sama pada kolom yang sama menunjukkan tidak nyata pada uji DMRT $5 \%$.

Mekanisme penyerapan unsur oleh mikoriza menurut Kaur et al. (2014) adalah jamur mikoriza melepaskan enzim seperti kitinase, peroksidase, selulase, dan protease yang memungkinkan jamur mikoriza dapat menembus substrat organic di dalam tanah. substrat organik yang telah terurai kemudian dapat diserap dan digunakan oleh jamur dan / atau tanaman inang sebagai energi dan sumber nutrisi untuk pertumbuhan dan reproduksi. Mikoriza dapat membantu akar tanaman dalam menyerap unsur Nitrogen (Jin et al., 2012), selain itu juga membantu penyerapan unsur Kalium (Garcia dan Zimmerman, 2014), serta penyerapan unsur $\mathrm{P}$ dimana mikoriza mempunyai extraradical hifa yang dapat membantu penyerapan $\mathrm{P}$ dan dapat mengubah biokimia dan fisiologis tanah antara tanaman dan jamur (Plassard dan Dell, 2010). Perbedaan penyerapan unsur hara tersebut yang dapat mempengaruhi terhadap pertumbuhan tanaman sehingga tanaman yang mempunyai kemampuan menyerap lebih banyak dan efektif mempunyai pertumbuhan lebih baik. Menurut Prajapati dan Modi (2012) unsur K dibutuhkan tanaman untuk proses fotosintesis dan untuk meningkatkan hasil panen tanaman, unsur $\mathrm{N}$ menurut Leghari et al. (2016) merupakan unsur yang paling penting dalam beberapa proses pertumbuhan fisiologis tanaman seperti pertumbuhan daun dan batang serta bagian vegetative tanaman lainnya, dan unsur $P$ menurut Malhotra et al. (2018) penting untuk tanaman akrena unsur $\mathrm{P}$ membantu pertumbuhan akar tanaman, luas daun tanaman, tinggi tanaman, jumlah daun serta meningkatkan perkecembahan benih dan vigor benih.

\section{Inkubasi patogen}

Berdasarkan hasil penelitian diperoleh hasil berbeda nyata pada perlakuan M4 dan M2 dengan kontrol. Munculnya gejala layu fusarium lebih lama pada tanaman dengan Mikoriza dibandingkan dengan tanaman yang tidak diberi perlakuan mikoriza. Layu fusarium pada perlakuan kontrol muncul rata-rata 5,4 hari setelah inokulasi dan pada tanaman tembakau yang dengan perlakuan mikoriza, inkubasi patogen lebih dari 5 hari. Perlakuan M4 menunjukkan terjadinya gejala terlama yang muncul 7,8 hari setelah inokulasi. Hal tersebut sesuai dengan penelitian yang dilakukan oleh Hasanah et al. (2007) dimana tanaman tomat yang di beri perlakuan mikoriza juga lebih lama muncul gejala layu Fusarium dibanding dengan tanaman yang tidak diberi mikoriza.

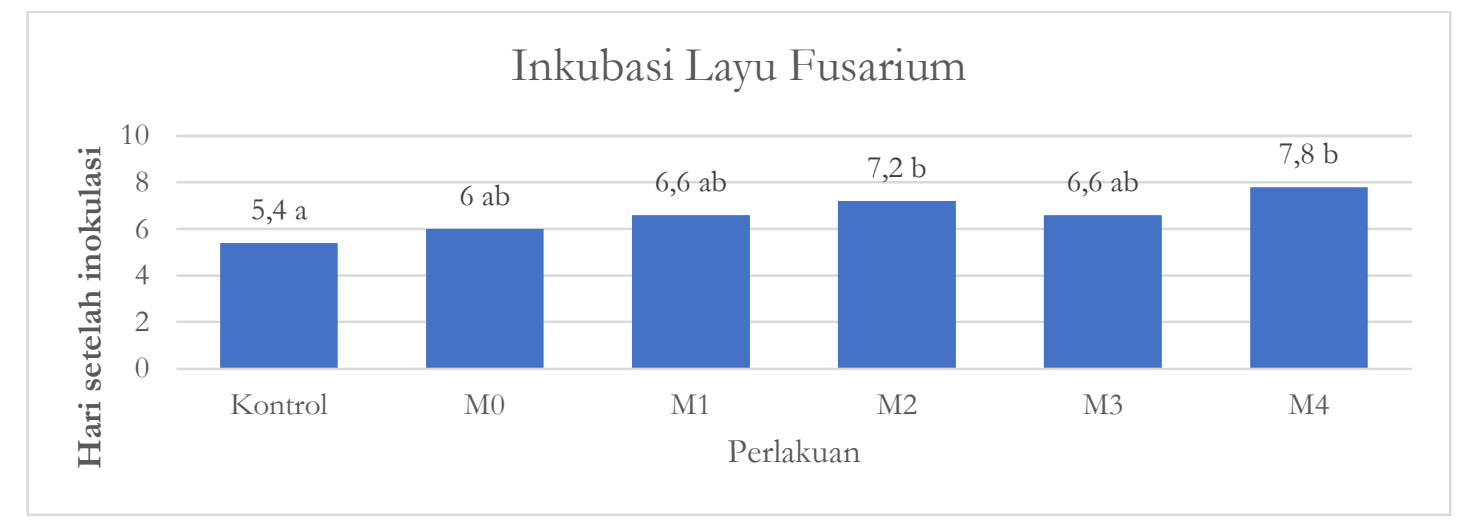

Keterangan: Bilangan yang diikuti huruf yang sama menunjukkan tidak nyata pada uji DMRT 5\%.

Gambar 1. Lama Inkubasi Patogen 


\section{Intensitas penyakit}

Dari hasil analisis ragam perhitungan IP pada 4 msi (Tabel 4), perlakuan M4 berbeda nyata dengan perlakuan M1, M0 dan kontrol dengan nilai IP sebesar $14,569 \%$. Penekanan penyakit terbesar terdapat pada perlakuan M4 yaitu sebesar $65.01 \%$. Mikoriza merupakan salah satu cara untuk pengendalian patogen, menurut penelitian Hao et al. (2015) mikoriza dapat mengurangi serangan layu fusarium dan juga dapat meningkatkan beberapa senyawa metabolit sekunder seperti prolin dan polifenol oksidase yang dapat mempertebal dan melindungi permeabilitas membrane tanaman

Tabel 4. Intensitas penyakit layu Fusarium

\begin{tabular}{clc}
\hline Perlakuan & IP (\%) & Penekanan (\%) \\
\hline Kontrol & $40,95 \mathrm{c}$ & \\
M0 & $30,83 \mathrm{~b}$ & 24,71 \\
M1 & $25,31 \mathrm{~b}$ & 38,19 \\
M2 & $21,87 \mathrm{ab}$ & 46,59 \\
M3 & $18,54 \mathrm{ab}$ & 54,72 \\
M4 & $14,56 \mathrm{a}$ & 65,01 \\
\hline
\end{tabular}

Keterangan: Bilangan yang diikuti huruf yang sama pada kolom yang sama menunjukkan tidak nyata pada uji DMRT 5\%.

\section{Kandungan asam salisilat}

Hasil uji asam salisilat diperoleh hasil perlakuan tembakau yang ditanam pada tanah konvensional (kontrol) mempunyai kandungan asam salisilat sebesar $0,31 \mathrm{mg}$, media AMB P0K tanpa mikoriza sebesar 0,86 dan pada media AMB-P0K dengan mikoriza mempunyai kandungan sebesar 0,90 (Tabel 5). Kandungan asam salisilat pada media tanah konvensional berbeda nyata dengan perlakuan AMB-P0K + sehingga mengurangi seranga $F$. oxysporum. Terdapat beberapa mekanisme mikoriza dalam mengurangi serangan patogen seperti merubah pertumbuhan morfologi akar tanaman sehingga akar tanaman lebih tahan terdapat patogen tular tanah, perubahan morfologis serta peningkatan senyawa metabolit sekunder serta sistem pertahanan pada tanaman yang dapat mengurangi patogen pada tanaman, peningkatan nutrisi dan unsur hara yang diserap tanaman sehingga tanaman lebih tahan terhadap penyakit, menyebabkan kompetisi antara mikoriza dan patogen khususnya patogen tular tanah sehingga patogen tular tanah pertumbuhannya (Akhtar dan Siddiqui, 2008).

Mikoriza, hal ini sesuai dengan penelitian Zhang et al. (2013) yaitu kandungan asam salisilat pada tanaman meningkat dengan diberikannya perlakuan mikoriza. Menurut Pozo dan Aguilar (2007) peningkatan asam salisilat dikarenakan saat pertama kali tanaman berinteraksi dengan mikoriza, tanaman menganggap mikoriza sebagai patogen dikarenakan ada sebagian gen protein mikoriza dianggap seperti patogen tanaman, setelah mikoriza sudah menembus korteks akar tanaman dan tanaman kompatibel dengan mikoriza, kandungan asam salisilat akan menurun kembali. Namun media AMB-P0K dengan AMB-P0K + mikoriza memiliki kandungan asam salisilat tidak berbeda nyata, hal tersebut dikarenakan media AMB-P0K mengandung kompos rumput gajah dimana rumput gajah yang dimana menurut Videira et al. (2012) jaringan daun, batang dan akar rumput gajah berkolonisasi dengan bakteri Gluconacetobacter dan Azorspirillum yang dimana bakteri tersebut juga menjadi biofertilizer serta PGPR. Menurut Widjayanti (2007) rizobakteri dapat meningkatkan asam salisilat yang sangat signifikan.

Tabel 5. Kandungan asam salisilat.

\begin{tabular}{cccccc}
\hline $\begin{array}{c}\text { Rata - Rata Kandungan Asam Salisilat Pada Akar } \\
\text { Tanaman Tembakau (mg) }\end{array}$ & \multicolumn{2}{c}{ Nilai probabilitas (p) } \\
\hline Perlakuan & Kontrol & AMB-P0K & $\begin{array}{c}\text { AMB-P0K } \\
+ \text { Mikoriza }\end{array}$ & $\begin{array}{c}\text { Kontrol } \\
\text { terhadap AMB } \\
\text { P0K }\end{array}$ & $\begin{array}{c}\text { AMB P0K terhadap } \\
\text { AMB-P0K + } \\
\text { Mikoriza }\end{array}$ \\
\hline $\begin{array}{c}\text { Kandungan } \\
\text { Asam } \\
\text { Salisilat (mg) }\end{array}$ & 0,31 & 0,86 & 0,90 & $0,00^{*}$ & 0,65 \\
\hline
\end{tabular}

Keterangan: angka pada nilai probabilitas yang diikuti tanda $\left(^{*}\right)$ berbeda nyata $(p<0.05)$ 
Tanaman dengan media tanam AMB dengan tambahan mikoriza mempunyai kandungan asam salisilat (AS) paling tinggi dan juga memperoleh IP paling kecil sedangkan pada perlakuan kontrol kandungan asam salisilat paling kecil dan memperoleh IP paling besar sehingga asam salisilat berkolerasi negatif dengan IP. Asam salisilat merupakan salah satu sinyal hormonal untuk mengaktifkan ketahanan tanaman saat tanaman terkena penyakit atau kondisi stress. Secara alami asam salisilat ditemukan pada tanaman dan terbukti terlibat dalam pertahanan tanaman terhadap infeksi patogen (Vlot et al., 2009). Asam salisilat dapat menginduksi ketahanan sistemik (SAR) pada tanaman dan asam salisilat berperan penting dalam aktivasi gen-gen yang mengendalikan ketahanan tanaman terhadap infeksi patogen dengan menginduksi protein yang terhubung dengan patogenesis yang berhubungan dengan anti patogen (Pieters et al., 2009). Asam salisilat juga merupakan sinyal untuk biosintesis enzim phenylalanine ammonia-lyase (PAL). PAL merupakan senyawa kuci untuk biosintesis fenolik pada tanaman yang dimana fenolik pada tanaman dapat berfungsi sebagai ketahan internal terhadap patogen (Zhang et al., 2013). PAL mengkatalisasi deaminasi L-fenilalanin menjadi asam t-sinamat, yang merupakan langkah pertama dalam jalur fenilpropanoid yang memasok prekursor untuk fenolat, lignin dan furanocoumarin, phytoalexins dan metabolit lainya (Quiroga et al., 2000). Menurut penelitian Zhang et al. (2013) diperoleh hasil asam salisilat berkolerasi positif dengan PAL dimana mikoriza dapat meningkatkan asam salisilat sehingga PAL juga meningkat. Penelitian Mandal et al. (2009) juga memperoleh hasil tanaman tomat yang diinduksi asam salisilat sebanyak $200 \mu \mathrm{M}$ hanya terserang sebanyak $25 \%$ pada minggu ke - 4 sedangkan tanaman tomat yang tidak diberi perlakuan asam salisilat pada minggu ke -4 sudah terserang $100 \%$ selain itu pada tanaman perlakuan asam salisilat mengalami peningkatan PAL. Asam salisilat tidak hanya menjadi pertahanan lokal pada tanaman tetapi asam salisilat juga berfungsi sebagai pelindung jaringan yang sehat pada tanaman (Kumar dan Almomin, 2018). Asam salisilat terhubung ke berbagai macam senyawa yang berfungsi sebagai pertahanan tanaman salah satunya. Semakin banyak asam salisilat pada tanaman maka pathogenesis related (PR) genes yang dihasilkan akan semakin bervariasi yang dimana PR genes ini berfungsi melindungi tanaman dari serangan patogen (Shah et al., 1997).

\section{Kesimpulan}

Perlakuan terbaik terdapat pada perlakuan AMB-P0K + mikoriza. Perlakuan M4 dapat meningkatkan luas daun tanaman, inkubasi patogen dan mengurangi intensitas serangan layu fusarium. Perlakuan M4 mampu menekan serangan layu fusarium hingga $65,1 \%$ dibanding kontrol dan dapat meningkatkan luas daun tanaman tembakau sebesar $62.1 \%$ dibanding kontrol. Laju pertumbuhan tinggi tanaman tertinggi terdapat pada perlakuan M2 dan laju pertumbuhan daun terdapat pada M1. Media AMB-P0K dengan tambahan mikoriza dapat meningkatkan kandungan asam salisilat tanaman tembakau sebanyak 190\% dibanding kontrol.

\section{Daftar Pustaka}

Boureima, S., Diouf M., Diop, T.A., Diatta, M., Leye, E.M., Ndiaye, F. and Seck, D. 2007. Effects of arbuscular mycorrhiza inoculation on the growth and the development of sesame (Sesamum indicum L.) African Journal of Agricultural Research 3 (3): 234-238

Et alAkhtar, M.S. and Siddiqui, Z. A. 2008. Arbuscular Mycorrhiza Fungi as Potential Bioprotectants Against Plant Patogens. In: Mycorrhizae: Sustainable Agriculture and Forestry. Siddiqui, Z.A (eds). Aligarh Muslim University. India. pp 61-97.

Febriani, W., Riniarti, M. dan Surnayanti. 2017. Penggunaan berbagai media tanam daninokulasi spora untuk meningkatkan kolonisasi ektomikoriza dan pertumbuhan Shorea javanica. Jurnal Sylva Lestari 5(3): 87-94.

Gao, H., Beckman, C.H. and Muller, W.C. 1994. The rate of vascular colonization as a measure of the genotype interaction between various cultivars of tomato and various formae or races of Fusarium oxysporum. Physiological and Molecular Plant Pathology 46 (1): 29-43.

Garcia, K. and Zimmermann, S.D. 2014. The role of mycorrhiza associations in plant potassium nutrition. Plant Science 5: 1-9.

Guo, Q.S., Chen, L.T. and Liu, Z.Y. 2010. Study on influence of arbuscular mycorrhiza fungi on 


\section{Jurnal Tanah dan Sumberdaya Lahan Vol 7 No 1 : 31-38, 2020 \\ e-ISSN:2549-9793, doi: 10.21776/ub.jts1.2020.007.1.5}

Pinellia ternata yield and chemical composition. Zhongguo Zhong Yao Za Zhi 35(3):333-338.

Hasanah, U., Purnomowati, dan Dwiputranto, U. 2007. Pengaruh inokulasi mikoriza vesikula arbuskula (MVA) campuran terhadap kemunculan penyakit layu fusarium pada tanaman tomat (Solanum bropersicum). Jurnal Scripta Biologica 4(1): 31-35.

Jin, H.R., Liu, J. and Huang, X.W. 2012. Forms of nitrogen uptake, translocation, and transfer via arbuscular mycorrhiza fungi: a review. China Life Science 55 (6): 474-482.

Kaur, R., Singh A., Kang, J.S. 2014. Influence of Different Types Mycorrhiza Fungi on Crop Productivity. Current Agriculture Research Journal 2 (1): 51-54.

Kumar, V. and Almomin, S. 2018. Plant defense against pathogens: the role of salicylic acid. Journal of Biotechnology 13(12): 97-103.

Leghari, S.J., Wahocho N.A., Laghari, M.G., Laghari, H.F., Bhabhan, G.M., Talpur, K.H., T.A., Wahocho, A. and Lashari, A.A. 2016. Role of nitrogen for plant growth and development: a review. Advances in Enviromental Biology 10(9): 209-218.

Malhotra, H., Vandana, S. Sharma, R. and Pandey, R. 2018. Phosphorus Nutrition: Plant Growth in Response to Deficiency and Excess. In: Plant Nutrients and Abiotic Stress Tolerance. Hasanuzzaman, M., Fujita M., Oku H., Nahar Kamrun., Nowak B (eds). Indian Agricultural Research Institute. India. pp 171-190

Mandal, S., Mallick, N. and Mitra, A. 2009. Salicylic acid-induced resistance to Fusarium oxysporum f. sp. lycopersici in tomato. Plant Physiology Biochemical 47(7): 642-9.

Muhibuddin, A. 2018. Spesifikasi Kandungan Nutrisi Kompos. Unwaha Press.

Pieterse, C.M., Leon, R.A, Van, D.E.S. and Wees, V. 2009. Networking by small-molecule hormones in plant immunity. Nature Chemical Biology 5: 308-316.

Plassard, C. and Dell ,B. 2010. Phosphorus nutrition of mycorrhiza trees. Tree Physiology 30 (9): 1129-1139.

Pozo, M.J. and Aguilar, A.C. 2007. Unraveling mycorrhiza induced resistance. Current Opinion in Plant Biology 10 (4): 393-398.

Prajapati, K. and Modi, H.A. 2012. The importance of potassium in plant growth - a review. Indian Journal of Plant Sciences 1(02): 177-186.

Pratiwi, Santoso, E. dan Turjaman, M. 2012. Penentuan dosis bahan pembenah (ameliorant) untuk perbaikan tanah dari tailing pasir kuarsa sebagai media tumbuh tanaman hutan. Jurnal Penelitian Hutan dan Konservasi Alam 9 (2): 163-174.
Quiroga, M., Guerrero, C., Botella, M.A., Barcelo, A., Amaya, I., Medina, M.I., Alonso, F.J., Forchetti, S.M., Tigier, H., Valpuesta, V. 2000. A Tomato Peroxidase Involved in the Synthesis of Lignin and Suberin. Plant Physiology 122(4): 1119 1127.

Shah, J., Tsui, F. and Klessig, D.F. 1997. Characterization of a salicylic acid-intensive mutant of Arabidopsis thaliana, identified in a selective screen utilizing the sa-inducible expression of the TMS2 Gene. Plant Microbe Interact 10(1): 69-78.

Suprapto, S.J. 2007. Tailing Sebagai Sumberdaya. Kementerian ESDM Pusat Sumberdaya Geologi.

Valentine, K., Herlina, N. dan Aini, N. 2017. Pengaruh pemberian mikoriza dan Trichoderma sp. terhadap pertumbuhan dan hasil produksi benih melon hibrida (Cucumis melo L.). Jurnal Produksi Tanaman 5(7): 1085-1092.

Videira, S.S., Oliveira, D.M., Morais, R.F., Borges, W.S., Baldani, V.L.D. and Baldani, J.I. 2012. Genetic diversity and plant growth promoting traits of diazotrophic bacteria isolated drom two Pennisetum Purpureum Schum. genotypes grown in the field. Plant and Soil 356(1): 51-66.

Vlot, A.C., Dempsey D.M.A. and Klessig D.F. 2009. Salicylic acid, multiefected hormone to combat disease. Annual Review Phytopathology 47(1): 177-206.

Wang ,J., Fu, Z., Ren, Q., Zhu, L., Lin, J., Zhang, J., Cheng, X., Ma, J. and Yue, J. 2019. Effects of arbuscular mycorrhiza fungi on growth, photosynthesis, and nutrient uptake of Zelkova serrata (Thunb.) makino seedlings under salt stress. Forest Article 10(2):1-16.

Widjayanti, K.S. 2007. Pengaruh rizobakteri dalam meningkatkan kandungan asam salisilat dan total fenol tanaman terhadap penekanan nematoda puru akar. Buletin Tanaman Tembakau, Serat \& Minyak Industri 9(2): 57-62.

Yang ,Y, Ou, X., Yang, G., Xia, Y., Chen, M., Guo, L. and Liu, D. 2017. Arbuscular mycorrhiza fungi regulate the growth and phyto-active compound of salvia miltiorrhiza seedlings. Applied Science $7(1)$ : 68-82.

Zhang, R.Q., Zhu, H.H., Zhao, H.Q. and Yao, Q. 2013. Arbuscular mycorrhiza fungal inoculation increases phenolic synthesis in clover roots via hydrogen peroxide, salicylic acid and nitric oxide signaling pathways. Journal of Plant Physiology 170(1): 74-79.

Zubek. S., Rola K., Szewczyk, A., Majewska, M.L. and Turnau, K. 2015. Enhanced concentrations of elements and secondary metabolites in Viola tricolor L. induced by arbuscular mycorrhiza fungi. Plant Soil 390(1):129-142. 